\title{
Invasive group A streptococcal disease: Management and chemoprophylaxis
}

UD Allen, DL Moore; Canadian Paediatric Society, Infectious Diseases and Immunization Committee

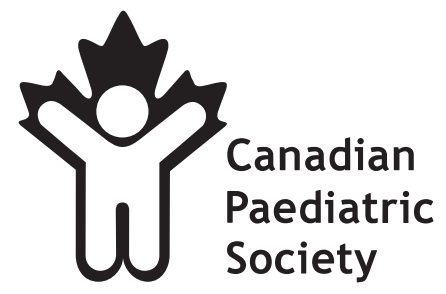

Français en page 299

UD Allen, DL Moore; Canadian Paediatric Society, Infectious Diseases and Immunization Committee. Invasive group A streptococcal disease: Management and chemoprophylaxis. Paediatr Child Health 2010;15(5):295-302.

Given the potentially devastating consequences of severe invasive group A streptococcal disease, attention has been directed toward the role of chemoprophylaxis and the optimization of management strategies. In response to this issue, Canadian guidelines were previously developed. However, the uptake of these recommendations is variable across Canada. The present document summarizes key components of the recommendations for use by Canadian physicians. The importance of penicillin in the treatment of group A streptococcal disease is reaffirmed, and the role of clindamycin is discussed. In addition, in situations in which chemoprophylaxis may be considered, the preferred agents are summarized.

Key Words: Chemoprophylaxis; Group A streptococcus; Necrotizing fasciitis; Toxic shock

Since the resurgence of severe group A streptococcal disSease in the 1980s, attention has been directed toward the role of chemoprophylaxis of contacts of invasive group A streptococcal disease, as well as the clinical management of individuals with this disease. In 2006, Canadian guidelines were developed to address the prevention and control of invasive disease due to group A streptococcus (GAS) (1). The present document highlights the management of contacts of cases of invasive group A streptococcal disease and the management of this disease based on the these guidelines.

\section{EPIDEMIOLOGY}

The most common clinical presentations of invasive group A streptococcal infections are necrotizing fasciitis (NF) or myositis, bacteremia with no septic focus and pneumonia. In Canada, the incidence of invasive group A streptococcal disease was 2.7 per 100,000 population, based on data from 2001 (2) (the most recent year for which complete data are available). Rates were highest in young children and the elderly. The rate among infants younger than one year of age was 4.8 per 100,000 , while the rate among children one to four years of age was 3.6 per 100,000 .

\section{L'infection à streptocoque envahissante du groupe A : La prise en charge et la chimioprophylaxie}

\begin{abstract}
Étant donné les conséquences au potentiel dévastateur d'une grave infection à streptocoque envahissante du groupe A, les auteurs se sont intéressés au rôle de la chimioprophylaxie et à l'optimisation des stratégies de prise en charge. À cet égard, des lignes directrices canadiennes ont déjà été mises en œuvre. Cependant, leur application est variable au Canada. Le présent document résume les principaux éléments des recommandations que doivent respecter les médecins canadiens. L'importance de la pénicilline dans le traitement de l'infection à streptocoque du groupe A est confirmée, et le rôle de la clindamycine est abordé. De plus, dans des situations où la chimioprophylaxie peut être envisagée, on fait la synthèse des antibiotiques à favoriser.
\end{abstract}

Among children, the annual incidence of NF has been shown to be higher in those younger than five years of age versus those five years to younger than 16 years of age (5.9 versus 1.8 per million; $\mathrm{P}=0.0002$ ) ( 3 ).

Invasive group A streptococcal infection may present as a severe disease manifested by toxic shock syndrome (TSS) with or without an identifiable focus of infection (4). Surveillance data from Ontario suggest that 13\% of cases of invasive group A streptococcal infection were streptococcal TSS and $6 \%$ were NF (5). Risk factors for invasive group A streptococcal disease among adults include HIV infection, cancer, heart disease, diabetes, lung disease, alcohol abuse, injection drug use and pregnancy-related risk factors. Among children, varicella is a prominent risk factor (5). Two studies $(5,6)$ assessing secondary cases in household contacts reported rates of 0.66 and 2.94 per 1000 , respectively, which were 20 to 100 times the rates in the overall populations studied. Most secondary cases occurred within seven days of the index case. There is little information on the risk of transmission in other settings, but secondary cases appear to be rare. A secondary case associated with varicella has been reported in a child care centre (7). Transmission also occurs in hospitals (8). 


\section{REPORTING INVASIVE GROUP A STREPTOCOCCAL INFECTION}

Currently, invasive group A streptococcal infection is reportable in all provinces and territories in Canada. Within each province or territory, procedures are in place for the rapid notification of cases to medical health officers and for timely reporting to the appropriate provincial/territorial public health official. Confirmed cases are reported at the national level.

\section{DEFINITIONS}

The Public Health Agency of Canada's (PHAC) "Guidelines for the prevention and control of invasive group A streptococcal disease" (1) are based on the following consensus definitions summarized below:

\section{Confirmed case}

- Laboratory confirmation of infection with or without clinical evidence of invasive disease.

- Laboratory confirmation requires the isolation of GAS (Streptococcus pyogenes) from a normally sterile site.

In the above context, clinical evidence of invasive disease includes the following:

a) streptococcal TSS, which is characterized by hypotension (systolic blood pressure of $90 \mathrm{mmHg}$ or less in adults, or less than the fifth percentile for age in children) and at least two of the following signs:

- renal impairment (creatinine level of $177 \mu \mathrm{mol} / \mathrm{L}$ or greater for adults)

- coagulopathy (platelet count of $100 \times 10^{9} / \mathrm{L}$ or lower, or disseminated intravascular coagulation)

- liver function abnormality (levels of aspartate aminotransferase, alanine aminotransferase or total bilirubin two times the upper limit of normal or greater)

- adult respiratory distress syndrome

- generalized erythematous macular rash that may desquamate;

b) soft-tissue necrosis, including NF, myositis or gangrene;

c) meningitis; or

d) a combination of the above.

\section{Severe case}

- Streptococcal TSS.

- Soft-tissue necrosis (NF, myositis or gangrene).

- Meningitis.

- Group A streptococcal pneumonia. (Pneumonia with isolation of GAS from a sterile site or from bronchoalveolar lavage [BAL] fluid should be regarded as a form of invasive disease for the purposes of public health management, if no other cause for the pneumonia has been identified. Given that BAL does not provide a sterile site specimen, pneumonia with GAS isolated only from BAL fluid would not meet the national case definition and would not be nationally notifiable.)

- Other life-threatening condition(s).

- Confirmed case resulting in death.

Probable case

- Invasive disease in the absence of another identified etiology and with isolation of GAS from a nonsterile site.

\section{Close contacts}

- Household contacts who have spent at least $4 \mathrm{~h}$ per day on average in the previous seven days or $20 \mathrm{~h}$ per week with the case.

- Nonhousehold persons who share the same bed with the case or had sexual relations with the case.

- Persons who have had direct mucous membrane contact with the oral or nasal secretions of a case (eg, mouth-tomouth resuscitation, open mouth kissing) or unprotected direct contact with an open skin lesion of the case.

- Injection drug users who have shared needles with the case.

- Selected contacts of long-term care facilities.

- Selected contacts in child care settings.

- Selected hospital contacts.

\section{CHEMOPROPHYLAXIS}

\section{Target group and prophylaxis window}

With respect to the role of chemoprophylaxis, the Canadian guidelines suggest the following:

- Chemoprophylaxis should only be offered to close contacts of a confirmed case of severe GAS, and to close contacts who have been exposed to the case during the period from seven days before the onset of symptoms in the case to $24 \mathrm{~h}$ after the initiation of antimicrobial therapy in the case.

- Chemoprophylaxis of close contacts should be administered as soon as possible and preferably within $24 \mathrm{~h}$ of case identification, but chemoprophylaxis is still recommended for up to seven days after the last contact with an infectious case.

- Close contacts of all confirmed cases (ie, regardless of whether the case is a severe one) should be alerted to signs and symptoms of invasive group A streptococcal disease, and be advised to seek medical attention immediately should they develop febrile illness or any other clinical manifestations of group A streptococcal infection within 30 days of diagnosis in the index case.

- Provincial/territorial protocols for prophylaxis may vary; clinicians should become familiar with local policies.

\section{Alternative courses of action}

Variations in the approach to chemoprophylaxis exist across jurisdictions $(9,10)$. The level of risk may vary for different groups of individuals, and there may be circumstances under which different decisions regarding chemoprophylaxis may 
TABLE 1

Recommended chemoprophylaxis regimens for close contacts of invasive group A streptococcal disease

\begin{tabular}{|c|c|c|}
\hline Drug & Dosage & Comments \\
\hline $\begin{array}{l}\text { First-generation cephalosporins: } \\
\text { cephalexin, cephadroxil } \\
\text { and cephradine }\end{array}$ & $\begin{array}{l}\text { First-line treatment: Children and adults: } 25 \mathrm{mg} / \mathrm{kg} \text { to } 50 \mathrm{mg} / \mathrm{kg} \\
\text { daily, to a maximum of } 1 \mathrm{~g} / \text { day in two to four divided doses for } \\
10 \text { days }\end{array}$ & $\begin{array}{l}\text { Recommended drug for pregnant and lactating women. } \\
\text { Should be used with caution in patients allergic to penicillin }\end{array}$ \\
\hline Erythromycin & $\begin{array}{l}\text { Second-line treatment: Children: } 5 \mathrm{mg} / \mathrm{kg} \text { to } 7.5 \mathrm{mg} / \mathrm{kg} \text { every } \\
6 \mathrm{~h} \text { or } 10 \mathrm{mg} / \mathrm{kg} \text { to } 15 \mathrm{mg} / \mathrm{kg} \text { every } 12 \mathrm{~h} \text { (base) for } 10 \text { days (not } \\
\text { to exceed maximum of adult dose). Adults: } 500 \mathrm{mg} \text { every } 12 \mathrm{~h} \\
\text { (base) for } 10 \text { days }\end{array}$ & $\begin{array}{l}\text { Erythromycin estolate is contraindicated in persons with } \\
\text { pre-existing liver disease or dysfunction, and during } \\
\text { pregnancy. Sensitivity testing is recommended in areas in } \\
\text { which macrolide resistance is unknown or known to be 10\% } \\
\text { or greater }\end{array}$ \\
\hline Clarithromycin & $\begin{array}{l}\text { Second-line treatment: Children: } 15 \mathrm{mg} / \mathrm{kg} \text { daily in divided } \\
\text { doses every } 12 \mathrm{~h} \text {, to a maximum of } 250 \mathrm{mg} \text { orally twice daily } \\
\text { for } 10 \text { days. Adults: } 250 \mathrm{mg} \text { orally twice daily for } 10 \text { days }\end{array}$ & $\begin{array}{l}\text { Contraindicated in pregnancy. Sensitivity testing is } \\
\text { recommended in areas in which macrolide resistance is } \\
\text { unknown or known to be } 10 \% \text { or greater }\end{array}$ \\
\hline Clindamycin & $\begin{array}{l}\text { Second-line treatment: Children: } 8 \mathrm{mg} / \mathrm{kg} \text { to } 16 \mathrm{mg} / \mathrm{kg} \text { daily } \\
\text { divided into three or four equal doses for } 10 \text { days (not to exceed } \\
\text { maximum of adult dose). Adults: } 150 \mathrm{mg} \text { every } 6 \mathrm{~h} \text { for } 10 \text { days }\end{array}$ & $\begin{array}{l}\text { Alternative for persons who are unable to tolerate beta- } \\
\text { lactam antibiotics }\end{array}$ \\
\hline
\end{tabular}

Adapted from reference 1

be made. Chemoprophylaxis is not routinely recommended for contacts of cases that are not severe (eg, bacteremia or septic arthritis). These cases tend to have milder disease and so do their contacts (1).

\section{Child care centres}

Chemoprophylaxis is recommended for all children and staff in family or home daycare settings if the above criteria are met. Chemoprophylaxis is generally not recommended in group or institutional child care centres and preschools. However, this may be considered in specific situations such as the occurrence of more than one case of invasive group A streptococcal disease in children or staff of the child care centre within one month, or the occurrence of a concurrent varicella outbreak at the child care centre.

\section{Choice of chemoprophylaxis agents}

The first-generation cephalosporins (eg, cephalexin) are the preferred agents (Table 1). Alternative agents include second-and third-generation cephalosporins (eg, cefuroxime axetil and cefixime). Penicillin is less effective in eradicating GAS colonization than the cephalosporins $(11,12)$. Macrolides, such as erythromycin, clarithromycin and azithromycin, may be used for chemoprophylaxis in individuals with beta-lactam allergy. However, this course of action would need to be periodically reassessed given the concern regarding macrolide-resistant GAS. Clindamycin may also be used for chemoprophylaxis in patients who are not able to tolerate beta-lactams.

\section{Follow-up cultures}

Routine cultures are not required for contacts receiving antibiotic chemoprophylaxis. Cultures have no role in the identification of asymptomatic close contacts of sporadic cases occurring in the community.

\section{MANAGEMENT OF SEVERE INVASIVE GROUP A STREPTOCOCCAL DISEASE}

The management of severe invasive group A streptococcal disease involves the following: supportive treatment with the use of fluid and electrolytes; specific therapy with antimicrobials; and the use of measures to minimize or neutralize the effects of toxin production, where indicated. Penicillin remains the treatment of choice (4). The addition of clindamycin is regarded as a more effective regimen than penicillin alone, because the antimicrobial activity of clindamycin is not affected by inoculum size, has a long postantimicrobial effect and acts by inhibiting protein synthesis (4). The latter is believed to be particularly relevant in cases of GAS in which there is no evidence of toxin-mediated disease. Clindamycin should not be used as monotherapy because a small proportion of group A streptococci are resistant to clindamycin ( $1 \%$ to $2 \%)(4)$, whereas, to date, there is no resistance to penicillin.

Intravenous immune globulin may be considered in the treatment of streptococcal TSS or severe toxin-mediated disease in the absence of shock. The mechanism of action of intravenous immune globulin is unclear. Suggested regimens include $150 \mathrm{mg} / \mathrm{kg}$ to $400 \mathrm{mg} / \mathrm{kg}$ per day for five days or a single dose of $1 \mathrm{~g} / \mathrm{kg}$ to $2 \mathrm{~g} / \mathrm{kg}(4,13,14)$.

Other specific treatments may be required depending on the clinical situation (eg, surgical debridement of necrotic tissue).

\section{LABORATORY SUPPORT}

The decision to engage the National Centre for Streptococcus in the investigations of clusters or outbreaks of disease due to GAS rests with the local public health agencies. Group A streptococcal strains are characterized using serological and molecular techniques. The profile of a particular strain includes the identification of the $\mathrm{M}$ protein type and $\mathrm{T}$ protein, and anti-opacity factor testing for serum opacity-factor-positive GAS (15-19).

\section{INFECTION CONTROL FOR INVASIVE GROUP A STREPTOCOCCAL DISEASE IN HEALTH CARE SETTINGS}

Readers are encouraged to consult the PHAC "Guidelines for the prevention and control of invasive group A streptococcal disease" (1) as well as the related infection control guidelines (20-22). These documents also address the prevention of noninvasive group A streptococcal disease within health care institutions. 


\section{REFERENCES}

1. Public Health Agency of Canada. Guidelines for the prevention and control of invasive group A streptococcal disease. CCDR 2006;32S2:1-26.

2. Health Canada. Notifiable diseases annual summary: 2001. CCDR 2004;30S3:92-4.

3. Eneli I, Davies HD. Epidemiology and outcome of necrotizing fasciitis in children: An active surveillance study of the Canadian Paediatric Surveillance Program. J Pediatr 2007;151:79-84.

4. American Academy of Pediatrics. Group A streptococcal infections. In: Pickering LK, Baker CJ, Kimberlin DW, Long SS, eds. Red Book 2009: Report of the Committee on Infectious Diseases, 28th edn. Elk Grove Village: American Academy of Pediatrics, 2009:616-28.

5. Davies HD, McGeer A, Schwartz B, et al. Invasive group A streptococcal infections in Ontario, Canada. Ontario Group A Streptococcal Study Group. N Engl J Med 1996;335:547-54.

6. Robinson KA, Rothrock G, Phan Q, et al; Active Bacterial Core Surveillance/Emerging Infections Program Network. Risk for severe group A streptococcal disease among patients' household contacts. Emerg Infect Dis 2003;9:443-7.

7. Centers for Disease Control and Prevention. Outbreak of invasive group A streptococcus associated with varicella in a childcare center - Boston, Massachusetts, 1997. MMWR 1997;46;944-8.

8. Daneman N, Green KA, Low DE, et al; Ontario Group A Streptococcal Study Group. Surveillance for hospital outbreaks of invasive group A streptococcal infections in Ontario, Canada, 1992 to 2000. Ann Intern Med 2007;147:234-41.

9. Prevention of Invasive Group A Streptococcal Infections Workshop Participants. Prevention of invasive group A streptococcal disease among household contacts of case patients and among postpartum and postsurgical patients:

Recommendations from the Centers for Disease Control and Prevention. Clin Infect Dis 2002;35:950-9.

10. Health Protection Agency, Group A Streptococcus Working Group. Interim UK guidelines for management of close community contacts of invasive group A streptococcal disease. Commun Dis Public Health 2004;7:354-61.

11. Casey JR, Pichichero ME. Meta-analysis of cephalosporins versus penicillin for treatment of group A streptococcal tonsillopharyngitis in children. Pediatrics 2004;113:866-82.
12. Casey JR, Pichichero ME. Meta-analysis of cephalosporins versus penicillin for treatment of group A streptococcal tonsillopharyngitis in adults. Clin Infect Dis 2004;38:1526-34.

13. Stevens DL. Dilemmas in the treatment of invasive Streptococcus pyogenes infections. Clin Infect Dis 2003;37:341-3.

14. Darenberg J, Ihendyane N, Sjölin J, et al; Streptlg Study Group. Intravenous immunoglobulin $\mathrm{G}$ therapy in streptococcal toxic shock syndrome: A European randomized, double-blind, placebo-controlled trial. Clin Infect Dis 2003;37:333-40.

15. Beall B, Gherardi G, Lovgren M, Facklam RR, Forwick BA, Tyrrell GJ. emm and sof gene sequence variation in relation to serological typing of opacity-factor-positive group A streptococci. Microbiology 2000;146:1195-209.

16. Beall B, Facklam RR, Elliott JA, et al. Streptococcal emm types associated with T-agglutination types and the use of conserved emm gene restriction fragment patterns for subtyping of group A streptococci. J Med Microbiol 1998;47:893-8.

17. Facklam RF, Martin DR, Lovgren M, et al. Extension of the Lancefield classification for group A streptococci by addition of 22 new $M$ protein gene sequence types for clinical isolates: emm103 to emm124. Clin Infect Dis 2002;34:28-38.

18. Facklam R, Beall B, Efstratiou A, et al. emm typing and validation of provisional M types for group A streptococci. Emerg Infect Dis 1999;5:247-53.

19. Tyrrell GJ, Lovgren M, Forwick B, Hoe NP, Musser JM, Talbot JA. $\mathrm{M}$ types of group A streptococcal isolates submitted to the National Centre for Streptococcus (Canada) from 1993 to 1999. J Clin Microbiol 2002;40:4466-71.

20. Health Canada. Routine practices and additional precautions for preventing the transmission of infection in health care. Revision of isolation and precaution techniques. CCDR 1999;25S4:1-142. <www.phac-aspc.gc.ca/publicat/ccdr-rmtc/99vol25/25s4/index.html> (Accessed on March 24, 2010).

21. Health Canada. Prevention and control of occupational infections in health care. CCDR 2002;28S1:1-264. <www.phac-aspc.gc.cal publicat/ccdr-rmtc/02vol28/28s1/index.html> (Accessed on March 24, 2010).

22. Health Canada. Hand washing, cleaning, disinfection and sterilization in health care. CCDR 1998;24S8:1-55. <www.phac-aspc.gc.ca/publicat/ccdr-rmtc/98pdf/cdr24s8e.pdf> (Accessed on March 24, 2010).

\section{INFECTIOUS DISEASES AND IMMUNIZATION COMMITTEE}

Members: Drs Robert Bortolussi, IWK Health Centre, Halifax, Nova Scotia (Chair); Jane Finlay, Richmond, British Columbia; Jane C McDonald, The Montreal Children's Hospital, Montreal, Quebec; Heather Onyett, Kingston General Hospital, Kingston, Ontario; Joan L Robinson, Edmonton, Alberta; Élisabeth Rousseau-Harsany, Sainte-Justine University Hospital Center, Montreal, Quebec (Board Representative)

Liaisons: Drs Upton D Allen, The Hospital for Sick Children, Toronto, Ontario (Canadian Pediatric AIDS Research Group); Charles PS Hui, Children's Hospital of Eastern Ontario, Ottawa, Ontario (CPS Liaison to Health Canada, Committee to Advise on Tropical Medicine and Travel); Nicole Le Saux, Children's Hospital of Eastern Ontario, Ottawa, Ontario (Immunization Program, ACTive); Larry Pickering, Elk Grove, Illinois, USA (American Academy of Pediatrics); Marina I Salvadori, Children's Hospital of Western Ontario, London, Ontario (CPS Liaison to Health Canada, National Advisory Committee on Immunization)

Consultants: Drs James Kellner, Calgary, Alberta; Noni E MacDonald, IWK Health Centre, Halifax, Nova Scotia; Dorothy L Moore, The Montreal Children's Hospital, Montreal, Quebec

Principal authors: Drs Upton D Allen, The Hospital for Sick Children, Toronto, Ontario; Dorothy L Moore, The Montreal Children's Hospital, Montreal, Quebec

The recommendations in this statement do not indicate an exclusive course of treatment or procedure to be followed. Variations, taking into account individual circumstances, may be appropriate. All Canadian Paediatric Society notes are reviewed, revised or retired as needed on a regular basis. Please consult the "Position Statements" section of the CPS Web site (www.cps.ca/english/publications/statementsindex.htm) for the most current version. This article also appears in the Autumn 2010 issue of The Canadian Journal of Infectious Diseases Eु Medical Microbiology. 